\title{
TINGKAT PENGETAHUAN IBU NIFAS TENTANG METODE AMENORE LAKTASI (MAL) DI KLINIK BERSALIN AISYAH MEDAN TAHUN 2016
}

\author{
Level of Knowledge of Childbirth Mother about Amenore Lactation (MAL) \\ Methods in Aisyah Maternity Clinic Medan 2016
}

\author{
Rhina Chairani Lubis ${ }^{1}$
}

${ }^{1}$ Dosen Tetap Akademi Kebidanan Indah Medan

Email : fathzaidan@yahoo.com

\begin{abstract}
Abstrak
Keefektifan Metode Amenore Laktasi (MAL) $89 \%$ bagi ibu menyusui secara ekslusif. Di Indonesia pencapaian MAL masih rendah yang diukur dari tingkat pencapaian Asi Ekslusif yang masih rendah. Penelitian dilakukan di Klinik Bersalin Aisyah yang bertujuan untuk mengetahui tingkat pengetahuan ibu nifas tentang Metode Amenore laktasi (MAL). Penelitian bersifat deskritif menggunakan kuesioner. Populasi adalah seluruh ibu nifas berkunjung ke Klinik Bersalin Aisyah sebanyak 30 orang. Pengambilan sampel dilakukan secara accidental sampling. Analisa data dilakukan secara deskriptif.

Hasil penelitian menunjukkan bahwa pengetahuan ibu mayoritas cukup yaitu 18 responden (60\%), umur mayoritas 20-35 tahun (87\%), pendidikan mayoritas SMA/SMK 16 responden (53\%), paritas mayoritas multipara 22 responden (73\%), dan sumber informasi mayoritas petugas kesehatan 21 responden (70\%). Berdasarkan penelitian diatas, dapat disimpulkan bahwa tingkat pengetahuan ibu nifas tentang Metode Amenore laktasi (MAL)di Klinik Bersalin Aisyah berpengetahuan cukup. Dianjurkan kepada ibu nifas agar kiranya dapat menambah wawasan tentang Metode Amenore Laktasi (MAL).

Kata kunci : tingkat pengetahuan, metode amenore laktasi (MAL)

Abstract

Effectiveness of Lactation Amenorrhea Method (MAL) $89 \%$ for exclusively breastfeeding mothers. In Indonesia the achievement of MAL is still low as measured by the achievement level of exclusive Asi which is still low. The study was conducted at the Aisyah Maternity Clinic which aims to determine the level of knowledge of postpartum mothers about the lactation Amenorrhea Method (MAL). Research is descriptive using a questionnaire. The population was all postpartum mothers visiting the Aisyah Maternity Clinic as many as 30 people. Sampling is done by accidental sampling. Data analysis was carried out descriptively.

The results showed that the majority of mothers' knowledge was enough, namely 18 respondents $(60 \%)$, the majority of the age of 20-35 years (87\%), the majority of high school/vocational education 16 respondents $(53 \%)$, multipara majority majority 22 respondents $(73 \%)$, source of information for the majority of health workers 21 respondents $(70 \%)$. Based on the above research, it can be concluded that the level of knowledge of postpartum mothers about the lactation Amenorrhea Method (MAL) in the Aisyah Maternity Clinic is sufficiently knowledgeable. It is recommended to postpartum mothers so that they can add insight into the Lactation Amenorrhea Method (MAL)
\end{abstract}

Keywords : knowledge level, lactation amenorrhea method

\section{PENDAHULUAN}

Laju pertumbuhan penduduk yang sangat tinggi dantidak seimbangnya penyebaran penduduk merupakan masalah utama di negara berkembang termasuk Indonesia. Keadaan ini dapat mempersulit pemerataan kesejahteraan rakyat (BKKBN, 2009). Untuk mewujudkan visi dan misi keluarga berencana nasional diperlukan upaya integral dalam meningkatkan kualitas keluarga. (Saifuddin, 2006).

Data Riset Kesehatan Dasar (Riskesdas, 2013) menunjukkan bahwa pada wanita dengan usia 15-49 tahun yang menggunakan KB sebesar $59,7 \%$ dan yang tidak menggunakan KB sebesar 40,2\%.

Metode amenore laktasi (MAL) merupakan kontrasepsi yang mengandalkan pemberian Air Susu Ibu (ASI) secara eksklusif sampai 6 bulan tanpa tambahan makanan atau minuman lain (Saifuddin, 2006). Hisapan mulut bayi pada puting susu merangsang ujung syaraf sensorik sehingga post anterior hipofise mengeluarkan prolaktin. Prolaktin masuk 
ke indung telur, menekan produksi estrogen dan menyebabkan tidak terjadi ovulasi (Haryono \& Setianingsih, 2014).

Menurut World Health Organization (WHO) keefektifan MAL 89\% pada ibu yang menyusui secara ekslusif 6 bulan pertama pasca persalinan dan sebelum menstruasi sebelum melahirkan (Prawirohardjo, 2006).

Salah satu faktor yang mempengaruhi penggunaan kontrasepsi MAL adalah pengetahuan. Pengetahuan adalah hasil tahu dan ini terjadi setelah orang melakukan pengindraan terhadap obyek tertentu. Pengetahuan merupakan domain yang sangat penting dalam membentuk tindakan seseorang (overt behaviour). Perilaku yang didasari oleh pengetahuan akan lebih baik dari pada perilaku yang tidak didasari oleh pengetahuan (Notoatmodjo, 2012).

Di Indonesia pencapaian MAL masih rendah hal ini diukur dari tingkat pencapaian pemberian Asi Eksklusif yang masih rendah. Menurut survei sosial ekonomi nasional tahun 2010, hanya $33,6 \%$ bayi 0-6 bulan yang mendapatkan ASI esklusif, rendahnya pemberian ASI esklusif disebabkan karena masih kurangnya pengetahuan tentang mamfaat ASI dan gencarnya promosi susu formula membuat ibu gagal menyusui. (Muryanto, 2012).

Data dari Profil Kesehatan 2013 menyatakan cakupan bayi yang diberi ASI Eksklusif dari tahun 2009-2012 cenderung menurun secara signifikan walaupun pada tahun 2013 mengalami peningkatan. Tetapi masih jauh dibawah pencapaian tahun 2009, sehingga belum mampu mencapai target nasional yaitu sebesar $40 \%$.

Adapun Kabupaten/Kota dengan pencapaian ASI eksklusif di atas $40 \%$ meliputi Deli Serdang (41,4\%), Langkat (42,7\%), Simalungun (43,6\%), Padang Sidempuan $(43,9 \%)$, Samosir $(45,9 \%)$, Pematang Siantar (46\%), Nias Utara ( 49,1\%), Nias Selatan $(49,9 \%)$. Sementara terdapat 5 Kabupaten/Kota dengan pencapaian bayi dengan ASI eksklusif $<10 \%$ yaitu Nias (7,7\%), Medan (7,6\%), Humbang Hasundutan (7,3\%), Tanjungbalai $(4,3 \%)$ dan Nias Barat (2\%) (Dinkes Sumut, 2013).

Hasil penelitian Puput Lestari menyatakan bahwa kategori pengetahuan baik sebanyak 14 responden (23,3\%), kategori pengetahuan cukup sebanyak 33 responden
(55,0\%), kategori pengetahuan kurang sebanyak 13 responden $(21,7 \%)$.

Berdasarkan hasil survei yang dilakukan peneliti di Klinik Bersalin Aisyah pada tanggal 23-30 Maret 2016 didapatkan data ibu nifas sebanyak 43 orang. Setelah dilakukan wawancara dengan 6 orang responden ternyata $100 \%$ ibu nifas tersebut tidak ada yang mengetahui tentang alat kontrasepsi Metode Amenore Laktasi.

Dari uraian tersebut maka penelitian mengenai tingkat pengetahuan ibu nifas tentang Metode Amenore Laktasi (MAL) perlu dilakukan. Tujuan penelitian ini adalah untuk mengetahui tingkat pengetahuan ibu nifas tentang Metode Amenore laktasi (MAL) di Klinik Bersalin Aisyah.

\section{METODE PENELITIAN}

Jenis penelitian ini adalah bersifat deskriptif yang dilakukan di Klinik Bersalin Aisyah padatanggal 23 - 30 Maret 2016. Populasi adalah seluruh ibu nifas yang sedang menyusui datang berkunjung keKlinik Bersalin Aisyah sebanyak 30 orang.Pengambilan sampel dilakukan secara accidental sampling. Instrumen penelitian yang digunakan adalahkuesioner. Analisa data dilakukan secara deskriptif.

\section{HASIL DAN PEMBAHASAN}

a. Karakteristik Responden

Karakteristik responden ini menjelaskan tentang distribusi rekuensi dan persentase masing-masing karakteristik responden.

Tabel 1. Distribusi Frekuensi Berdasarkan Karakteristik Responden Di Klinik Bersalin Aisyah

\begin{tabular}{llcc}
\hline Karakteristik Responden & F & $(\%)$ \\
\hline \multicolumn{3}{c}{ Umur } \\
1 & $<20$ & 1 & $3 \%$ \\
2 & $20-35$ & 26 & $87 \%$ \\
3 & $>35$ & 3 & $10 \%$ \\
& Jumlah & 30 & $100 \%$ \\
\hline \multicolumn{5}{c}{ S } & Pendidikan \\
2 & SMP & 5 & $17 \%$ \\
& & 9 & $30 \%$
\end{tabular}




\begin{tabular}{llcc}
3 & SMA/SMK & 16 & $53 \%$ \\
4 & Perguruan Tinggi & - & - \\
\multicolumn{2}{l}{ Jumlah } & 30 & $100 \%$ \\
\hline Paritas & & \\
1 & Primipara & 7 & $23 \%$ \\
2 & Multipara & 22 & $73 \%$ \\
3 & Grandemultipara & 1 & $34 \%$ \\
& Jumlah & 30 & $100 \%$ \\
\hline Sumber Informasi & & \\
1 & Media Elektronik & - & - \\
2 & Media Cetak & 2 & $6,7 \%$ \\
3 & Petugas Kesehatan & 21 & $70 \%$ \\
4 & Teman/Keluarga & 7 & $23,3 \%$ \\
& Jumlah & 30 & $100 \%$ \\
\hline
\end{tabular}

Dari tabel 1 di atas dapat disimpulkan bahwa dari 30 Responden mayoritas berumur 2035 tahun sebanyak 26 responden (87\%) dan minoritas umur $<20$ tahun sebanyak 1 responden $(3 \%)$.

Menurut Manuaba (1998) usia reproduksi dibagi dua reproduksi sehat umur 20-35 tahun dan reproduksi tidak sehat umur $<20$ tahun $>35$ tahun.Menurut peneliti, penelitian ini sejalan dengan teori Manuaba (1998), dengan kategori umur $<20$ tahun, 20-35 tahun, $>35$ tahun.

Pendidikan mayoritas SMA/SMK sebanyak 16 responden (53\%), dan minoritas SD sebanyak 5 responden (17 \%). Menurut Departemen Pendidikan Nasional (2003) berupa UU RI No.20 Tahun 2003 tentang pendidikan Nasional menyebutkan bahwa pendidikan dibagi menjadi tiga yaitu pendidikan dasar meliputi SD/SMP, pendidikan menengah meliputi SMA/SMP, dan pendidikan perguruan tinggi.

Menurut peneliti, penelitian ini sesuai dengan teori Menurut Departemen Pendidikan Naisonal (2003) berupa UU RI No.20 Tahun 2003 pendidikan dibagi menjadi tiga yaitu pendidikan dasar meliputi SD dan SMP, pendidikan menengah meliputi SMA/SMK, dan pendidikan perguruan tinggi. $\begin{array}{rcr}\text { Paritas } & \text { mayoritas } & \begin{array}{r}\text { Multipara } \\ \text { sebanyak } 22\end{array} \\ \text { responden } & (73 \%) \text {, dan }\end{array}$ minoritas Grandemultipara 1 responden (3\%). Menurut Nursalam (2001), pengalaman merupakan pendekatan yang penting dalam memecahkan masalah. Paritas di bagi menjadi 3 yaitu primipara (wanita yuang telah melahirkan anak 1 kali dengan usia kehamilan >28 minggu, Multipara (seorang wanita yang telah melahirkan lebih dari seorang anak), Grandemultipara (wanita yang melahirkan lebih dari lima orang anak).Menurut peneliti, hasil penelitian ini sesuai dengan teori Nursalam (2001) dimana paritas multipara berpengetahuan lebih banyak dibandingkan dengan paritas grandemultipara.

Kemudian Sumber Informasi mayoritas dari Petugas kesehatan sebanyak 21 responden $(70 \%)$, dan Minoritas dari Media cetak sebanyak 2 responden $(6,7 \%)$.

Notoatmodjo (2012) menyampaikan bahwa pengetahuan juga dipengaruhi oleh sumber informasi. Informasi dapat diperoleh dari berbagai sumber yaitu Media Elektronik merupakan salah satu perantara yang digunakan oleh sumber untuk mengirim pesan berupa televisi dan radio, Media Papan merupakan salah satu alat bantu untuk menyampaikan informasi kepada masyarakat spanduk, buletin. Media Cetakadalah suatu alat yang digunakan sebagai perantara untuk menginfor-masikan suatu hal kepada masyarakat dalam bentuk cetak berupa koran, majalah, buku, dan pamflet, Petugas KesehatanPengetahuan dapat diperoleh secara langsung dari petugas kesehatan, teman dan keluarga.

\section{b. Pengetahuan Ibu Nifas TentangMetode Amenore Laktasi (MAL) Di Klinik Bersalin Aisyah}

Analisis ini menjelaskan distribusi dan frekuensi Pengetahuan Ibu Nifas Tentang Metode Amenore Laktasi (MAL) Di Klinik Bersalin Aisyah.

Tabel 2. Distribusi Frekuensi Pengetahuan Ibu Nifas Tentang Metode Amenore Laktasi (MAL) Di Klinik Bersalin Aisyah

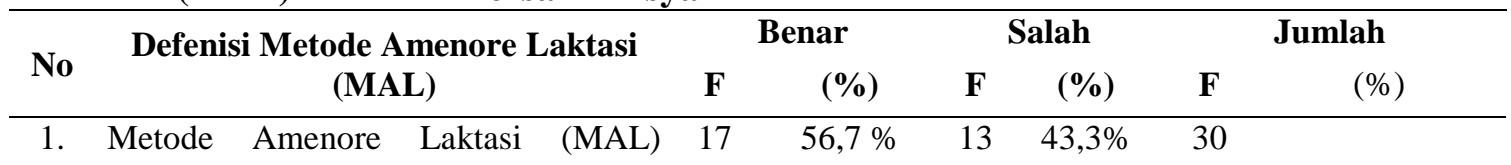




\begin{tabular}{|c|c|c|c|c|c|c|c|}
\hline & $\begin{array}{l}\text { pemberian Air Susu Ibu (ASI) selama } \\
6 \text { bulan tanpa tambahan } \\
\text { makanan/minuman lainnya. } \\
\text { Jumlah rata-rata }\end{array}$ & 17 & $56,7 \%$ & 13 & $43,3 \%$ & 30 & $100 \%$ \\
\hline \multicolumn{8}{|c|}{ Pesyaratan Metode Amenore laktasi (MAL) } \\
\hline 2 & $\begin{array}{l}\text { Menyusui secara ekslusif selama } 6-8 \\
\text { jam/hari }\end{array}$ & 24 & $80 \%$ & 6 & $20 \%$ & 30 & \multirow[b]{3}{*}{$100 \%$} \\
\hline 3 & $\begin{array}{l}\text { Dapat dilakukan setelah melahirkan } \\
\text { dan belum mendapat haid. }\end{array}$ & 20 & $66,7 \%$ & 10 & $33,3 \%$ & 30 & \\
\hline & Jumlah rata-rata & 22 & $73,3 \%$ & 8 & $26,7 \%$ & 30 & \\
\hline \multicolumn{8}{|c|}{ Keuntungan Metode Amenore Laktasi (MAL) } \\
\hline 4. & $\begin{array}{l}\text { Tidak membutuhkan biaya dan tidak } \\
\text { mengganggu senggama }\end{array}$ & 21 & $70 \%$ & 9 & $30 \%$ & 30 & \multirow[b]{3}{*}{$100 \%$} \\
\hline \multirow[t]{2}{*}{5.} & $\begin{array}{l}\text { Tidak perlu menggunakan obat-obatan } \\
\text { dan pengawasan oleh tenaga kesehatan }\end{array}$ & 15 & $50 \%$ & 15 & $50 \%$ & 30 & \\
\hline & Jumlah rata-rata & 18 & $60 \%$ & 12 & $40 \%$ & 30 & \\
\hline \multicolumn{8}{|c|}{ Keterbatasan Metode Amenore Laktasi (MAL) } \\
\hline 6. & $\begin{array}{l}\text { Sulit dilakukan oleh ibu yang bekerja } \\
\text { dan perlu persiapan sejak masa } \\
\text { kehamilan }\end{array}$ & 22 & $73,3 \%$ & 8 & $26,7 \%$ & 30 & \\
\hline 7. & $\begin{array}{l}\text { Tidak melindungi terhadap penyakit } \\
\text { menular seksual }\end{array}$ & 14 & $46,7 \%$ & 16 & $53,3 \%$ & 30 & \multirow[b]{2}{*}{$100 \%$} \\
\hline & Jumlah rata-rata & 18 & $60 \%$ & 12 & $40 \%$ & 30 & \\
\hline \multicolumn{8}{|c|}{ Yang dapat menggunakan Metode Amenore Laktasi (MAL) } \\
\hline \multirow[t]{2}{*}{8.} & $\begin{array}{l}\text { Belum mendapat haid setelah } \\
\text { melahirkan dan bayi berumur kurang } \\
\text { dari } 6 \text { bulan. }\end{array}$ & 18 & $60 \%$ & 12 & $40 \%$ & 30 & \multirow[b]{2}{*}{$100 \%$} \\
\hline & Jumlah rata-rata & 18 & $60 \%$ & 12 & $40 \%$ & 30 & \\
\hline \multicolumn{8}{|c|}{ Yang tidak dapat menggunakan Metode Amenore Laktasi (MAL) } \\
\hline \multirow[t]{2}{*}{9} & \multirow{2}{*}{$\begin{array}{l}\text { Sudah mendapat haid dan bayi sudah } \\
\text { berumur lebih dari } 6 \text { bulan. } \\
\text { Jumlah rata-rata }\end{array}$} & 28 & $93,3 \%$ & 2 & $6,7 \%$ & 30 & \multirow[b]{2}{*}{$100 \%$} \\
\hline & & 28 & $93,3 \%$ & 2 & $6,7 \%$ & 30 & \\
\hline \multicolumn{8}{|c|}{ Manfaat Metode Amenore Laktasi (MAL) } \\
\hline 10. & $\begin{array}{l}\text { Bayi mendapatkan kekebalan tubuh } \\
\text { lewat Air susu ibu dan tidak } \\
\text { menimbulkan efek samping. }\end{array}$ & 15 & $50 \%$ & 15 & $50 \%$ & 30 & \\
\hline & Jumlah rata-rata & 15 & $50 \%$ & 15 & $50 \%$ & 30 & $100 \%$ \\
\hline
\end{tabular}


Dari tabel 2 di atas dapat disimpulkan bahwa dari 30 responden yang diteliti, tentang Defenisi Metode Amenore Laktasi (MAL) mayoritas menjawab benar sebanyak

Responden (56,7\%), dan

minoritas menjawab salah sebanyak 13 responden (43,3\%). Pernyataan Persyaratan Metode Amenore Laktasi (MAL) mayoritas menjawab benar sebanyak 24 Responden $(80 \%)$ yaitu pada pernyataan nomor 2 dan minoritas menjawab benar sebanyak 20 responden $(66,7 \%)$ pada pernyataan nomor 3.Pernyataan Keuntungan Metode Amenore Laktasi (MAL)mayoritas menjawab benar sebanyak 21 responden $(70 \%)$ pada pernyataan nomor 4 dan minoritas menjawab benar sebanyak 15 responden (50\%) pada pernyataan nomor 5. Pernyataan keterbatasan Metode Amenore Laktasi (MAL) mayoritas menjawab benar sebayak 22 responden $(73,3 \%)$ pada pernyataan nomor 6 , dan minoritas menjawab benarsebanyak 14 responden $(46,7 \%)$ pada pernyataan nomor 7 . Pada Pernyataan yang dapat menggunakan Metode Amenore Laktasi (MAL) mayoritas menjawab benar sebanyak 18 Responden (60\%), dan minoritas menjawab salah sebanyak 12 responden $(40 \%)$ pada pernyataan nomor 8.Pada pernyataan yang tidak dapat menggunakan Metode Amenore Laktasi (MAL) mayoritas menjawab benar sebanyak 28 Responden (93,3\%), dan minoritas menjawab salah sebanyak 2 Responden $(6,7 \%)$ pada pernyataan nomor 9 . Pada pernyataan Manfaat Metode Amenore Laktasi (MAL) mayoritas menjawab benar sebanyak 15 Responden (50\%).

Menurut Setianingrum (2016) Metode Amenore Laktasi (MAL) adalah kotrasepsi yang mengandalkan pemberian Air Susu Ibu (ASI) secara eksklusif, artinya hanya diberikan ASI tanpa tambahan makanan ataupun minuman apapun lainnya.Menurut peneliti, penelitian ini sesuai dengan teori Setianingrum (2016) responden dikategorikan berpengetahuan cukup dalam menjawab pernyataan tentangPengertian Metode Amenore Laktasi.

Menurut Setianingurm (2016) persyaratan Metode Amenore Laktasi yaitu Ibu yang menyusui secara eksklusif, ibu belum menstruasi sejak melahirkan, ibu memberikan Asi kepada bayinya secara penuh, bayi berusia 6 bulan.
Menurut peneliti, penelitian ini sesuai dengan teori Setianingrum (2016) repsondendikategorikan berpengetahuan baik dalam menjawab pernyataan tentang Persyaratan Metode Amenore Laktasi (MAL).

Menurut Anggraini, dkk, (2016) Keuntungan Metode Amenore Laktasi sebagai berikut Efektivitas tinggi (keberhasilan 98\% pada enam bulan pascapersalinan), Segera efektif, tidak mengganggu senggama, tidak ada efek samping secara sistemik, tidak perlu pengawasan medis, tidak perlu obat atau alat, tanpa biaya.

Menurut peneliti, penelitian ini sesuai dengan teori Anggraini, dkk (2016) reponden dikategorikan berpengetahuan cukup dalam menjawab pernyataan tentang Keuntungan Metode Amenore Laktasi (MAL)

Menurut Setiyaningrum keterbataasan Metode Amenore Laktasi yaitu sebagai berikut, perlu persiapan sejak perawatan kehamilan agar segera menyusui dalam 30 menit pascapersalinan, Mungkin sulit dilaksanakan karena kondisi sosial, Efektivitas tinggi hanya sampai kembalinya haid atau sampai dengan 6 bulan, tidak melindungi terhadap IMS termasuk virus hepatitis $\mathrm{B} / \mathrm{HBV}$ dan HIV/AIDS dan virus hepatitis $\mathrm{B} / \mathrm{HBV}$.

Menurut peneliti, penelitian ini sesuai dengan teori Setiyaningrum (2016) responden dikategorikan cukup dalam menjawab pernyataan tentang Ketebatasan Metode Amenore Laktasi (MAL).

Setyaningrum (2016), yang dapat menggunakan Metode Amenore Laktasi yaitu sebagai berikut wanita yang menyusui secara ekslusif, Ibu pasca melahirkan dan bayinya berumur kurang dari 6 bulan, Wanita yang belum mendapat haid pasca persalinan.

Dan tidak dapat menggunakan Metode Amenore Laktasi yaitu udah mendapat haid setelah persalinan, tidak menyusui secara eksklusif, bayi sudah berumur lebih dari 6 bulan, bekerja dan terpisah dari bayi lebih lama dari 6 jam.

Anggrani, dkk (2016) manfaat Metode Amenore Laktasi yaitu efektifitas tinggi $98 \%$ apabila digunakan selama enam bulan pertama setelah melahirkan, belum mendapat haid dan menyusui eksklusif, tidak memerlukan prosedur khusus, alat maupun obat-obatan, tidak mengganggu senggama, tidak menimbulkan efek samping, tidak bertentangan denganb budaya maupun agama. 
Menurut Hendra (2008) bahwa daya ingat seseorang itu salah satunya dipengaruhi oleh umur. Bertambahnya umur seseorang dapat berpengaruh pada pertambahan pengetahuan yang diperolehnya, akan tetapi pada umur menjelang usia lanjut kemampuan penerimaan atau mengingat suatu pengetahuan akan berkurang.

Menurut Ajunk (2009), tingkat pendidikan seseorang akan membantu orang tersebut untuk lebih mudah menangkap dan memahami suatu informasi.Semakin tinggi pendidikan seseorang,maka tingkat pemehaman juga semakin meningkat serta tepat dalam pengambilan sikap.

Menurut peneliti, penelitian ini sesuai dengan teori Ajunk (2009). Dimana mayoritas ibu berpengetahuan baik pada pendidikan SMA/SMK di karenakan semakin tinggi pendidikan seseorang maka semakin banyak pengetahuan yang diperolehnya dan penerimaan tentang sumber informasi.

\section{KESIMPULAN}

1. Dari 30 Responden Mayoritas Berpengetahuan Cukup sebanyak 18 responden (60\%).Mayoritas berumur 20-35 sebanyak 26 responden (87\%). Mayoritas berpendidikan SMA/SMK sebanyak 16 responden (53\%). Paritas Mayoritas MultiparaSebanyak 22 responden (73\%), Dan mayoritas memperolehSumber Informasi dari Petugas Kesehatan sebanyak 21 responden $(70 \%)$.

2. Dari 30 berdasarkan Defenisi Metode Amenore Laktasi (MAL) mayoritas menjawab benar sebanyak 17 Responden ( $56,7 \%$ ). Persyaratan Metode Amenore Laktasi (MAL) mayoritas menjawab benar sebanyak 24 Responden (80\%). Keuntungan Metode Amenore Laktasi (MAL) mayoritas menjawab benar sebanyak 21 responden (70\%). Keterbatasan Metode Amenore Laktasi (MAL) mayoritas menjawab benar sebayak 22 responden (73,3\%), yang dapat menggunakan Metode Amenore Laktasi (MAL) mayoritas menjawab benar sebanyak 18 Responden ( $60 \%$ ). Tidak dapat menggunakan Metode Amenore Laktasi (MAL) mayoritas menjawab benar sebanyak 28 Responden (93,3\%). Manfaat Metode Amenore Laktasi (MAL) mayoritas menjawab benar sebanyak 15 Responden $(50 \%)$.

\section{SARAN}

a. Bagi Ibu Nifas

Diharapkan dapat menambah pengetahuan ibu menyusui terutama tentang persyaratan, manfaat, keuntungan serta keterbatasan menggunakan MAL dan yang tidak boleh menggunakan MAL. Kemudian banyak membaca, melihat informasi dari berbagai media (media masa, media cetak, media elektronik, petugas kesehatan, teman dan keluarga).

\section{b. Tenaga Kesehatan}

Bagi bidan diharapkan agar memberikan penyuluhanatau sosialisaidan informasi yang lebih lengkapterutama tentang keuntungan MAL dan memberikan dukungan kepada ibu nifas agar menyusui secara eksklusif.

\section{DAFTAR PUSTAKA}

BKKBN. 2009. Program keluarga berencana nasional. Jakarta:BKKBN

Dinas Kesehatan Kota, 2013. Profil Kesehatan Provinsi Sumatera Utara Tahun 2013. Medan.

Haryono., Setianingsih. 2014. Manfaat ASI Eksklusif untuk Buah Hati Anda. Yogyakarta: Gosyen Publishing

Lestari Puput, 2013. Tingkat Pengetahuan Ibu Menyusui tentang Kontrasepsi Metode Amenore Laktasi di RSUD kota Surakarta. pdf

Muryanto. 2012. Amenore Laktasi sebagai Metode ber-KB tahun 2012.

Notoatmodjo, Soekidjo.2012. Promosi kesehatan dan Perilaku Kesehatan. Jakarta: Rinekacipta

Prawihardjo. S., 2006. Buku Panduan Praktis Pelayanan Kontrasepsi. Jakarta: Yayasan Bina Pustaka Sarwono Prawiroharjdo.

Profil Kesehatan Indonesia, 2013.

Riset Kesehatan Dasar, 2013

Saifuddin. 2006. Buku Panduan Praktis Pelayanan Kontrasepsi. Jakarta : Penerbit Yayasan Bina Pustaka Sarwono Prawiroharjdo. 